\title{
Biotechnological production of galactooligosaccharides (GOS) using porungo cheese whey
}

\author{
Lais Saldanha BOLOGNESI ${ }^{1}$, Sabrina GABARDO ${ }^{2 *}$ (D), Paulo Roberto DALL CORTIVO ${ }^{3}$, \\ Marco Antônio Záchia AYUB 3
}

\begin{abstract}
The bioconversion of porungo cheese whey into galactooligosaccharides (GOS) was investigated using immobilized $\beta$-galactosidase in batch system. Two enzymatic immobilization strategies were tested for optima $\mathrm{pH}$ and temperature and the best immobilization strategy was used to evaluate the GOS production in two steps. First, different lactose sources (substrates) were tested, and subsequently, different concentrations of porungo cheese whey $\left(200 \mathrm{~g} \mathrm{~L}^{-1}\right.$ and $\left.400 \mathrm{~g} \mathrm{~L}^{-1}\right)$ and temperatures $\left(37^{\circ} \mathrm{C}\right.$ to $\left.46^{\circ} \mathrm{C}\right)$ were evaluated. Immobilization of $\beta$-galactosidase increased the range of operational $\mathrm{pH}$ (7.0-7.5) when immobilized in calciumalginate support. However, the $\mathrm{pH}$ range decreased when the immobilization was conducted using calcium-Concanavalin $\mathrm{A}$ support. Batch reactions using the calcium-alginate immobilized biocatalyst produced the highest yields of GOS (63.2\%) from porungo cheese whey, compared to the control substrate of lactose solution at concentration of $50 \mathrm{~g} \mathrm{~L}^{-1}(41.1 \%)$. The temperature of $46^{\circ} \mathrm{C}$ and $400 \mathrm{~g} \mathrm{~L}^{-1}$ of substrate shown the better condition to GOS production, with lactose conversion of $61.4 \%$. These results suggest the possible use of porungo cheese whey as substrate in the biotechnological production of GOS.
\end{abstract}

Keywords: agro-industrial residues; galactooligosaccharides; immobilized enzyme; whey; $\beta$-galactosidase.

Practical Application: Porungo cheese whey is a potential agro-industrial by-product to obtain GOS.

\section{Introduction}

The utilization of agro-industrial residues, such as cheese whey, as an alternative and cheap substrate in the bioprocess to obtain biomolecules has been researched in the generation of added-values products, such as galactooligosaccharides (GOS), important prebiotics used in the food industry. Agro-industrial sector is characterized by generating high amounts of residues, which can be used in bioprocesses, reducing their environmental impact and allowing to obtain value-added commercial products of interest (Laufenberg et al., 2003; Christensen et al., 2011; Gabardo et al., 2014; Trindade et al., 2019).

Cheese whey is a dairy industrial residue, possessing a high organic load in terms of BOD (Biochemical Oxygen Demand), which is produced in large volumes, thus being characterized as potentially polluting stream (Siso, 1996; Prazeres et al., 2012; Guimarães et al., 2010; Das et al., 2016; Fangmeier et al., 2019). The improper discharge of these residues also represents a major economic loss for the dairy industry since approximately half of the production is disposed in wastewater treatment plants or used as by-products for animal feed (Guimarães et al., 2010; Prazeres et al., 2012; Das et al., 2016; Trindade et al., 2019). On the other hand, because of its unique chemical composition, cheese whey has the potential to be used in bioprocess (Gabardo et al., 2014), consisting as a rich substrate for GOS production because of its high lactose content (45-50 $\left.\mathrm{g} \mathrm{L}^{-1}\right)$, and due to others nutritional components such as protein $\left(6-8 \mathrm{~g} \mathrm{~L}^{-1}\right)$, lipids $\left(4-5 \mathrm{~g} \mathrm{~L}^{-1}\right)$, and mineral salts $\left(5-7 \mathrm{~g} \mathrm{~L}^{-1}\right)$, also can be used to obtain different products with high nutritional value and functional properties (Fangmeier et al., 2019; Kelleher et al., 2020; Rasouli et al., 2020; Trindade et al., 2019). Porungo cheese, which is a local type of cheese produced by farmers located in the southwest of the state of São Paulo, Brazil, has similar characteristics to mozzarella cheese, but the whey produced in this process has so far found no applications (Pezzo, 2017).

In bioprocess, cheese whey can be used as an alternative source of lactose, the substrate of $\beta$-galactosidase enzyme (EC 3.2.1.23) for the biosynthesis of GOS. Classified as non-digestible dietary fiber by the human organism, this oligosaccharide act as a prebiotic and selectively increase beneficial intestinal microflora activity to generate health benefits (Gibson et al., 2010; Gosling et al., 2011). Prebiotics can be defined as selectively fermented food ingredients that induce specific changes in the composition and activity of the gastrointestinal microbiota, such as Bifidobacterium and Lactobacillus genera, conferring benefits upon host wellbeing and health (Gibson et al., 2010; Davani-Davari et al., 2019). Its classification is based on three criteria: (i) resistance to acidic $\mathrm{pH}$ of stomach, (ii) fermentation by intestinal microbiota, and (iii) selective stimulation of growth and/or activity of the health-promoting bacteria in that microbiota (Roberfroid, 2008; Davani-Davari et al., 2019). Although prebiotic activity has been mainly attributed to oligosaccharides 
and polysaccharides, it must be stressed that not all dietary non-digestible carbohydrates are prebiotics (Roberfroid, 2008; Davani-Davari et al., 2019). Beneficial effects of GOS ingestion include the increase in the colon bifidobacterial population and the suppression of pathogenic bacteria activity, leading to the reduction of toxic metabolism formation (Gibson \& Roberfroid, 1995; Fai \& Pastore, 2015).

$\beta$-galactosidase performs transgalactosylation reactions in high lactose concentration media and high temperatures, producing galactooligosaccharides by transferring galactosyl residues to lactose molecules (Klein et al., 2013; Nath et al., 2013). One way to improve the performance of this process is using enzymatic immobilization techniques. Among the main advantages of the technique are improvements in the operational stability and allowing enzyme recovery and reuse (Grosová et al., 2008). The use of low cost supports such as alginate is an interesting alternative for the industrial use of immobilized enzymes. This support has advantages such as high enzymatic retention, resistance to $\mathrm{pH}$ and temperature variations. As it has low physical stability, this problem can be overcome using crosslinking agents, such as glutaraldehyde and concanavalin A (ConA) (Haider \& Husain 2007; Freitas et al., 2011).

In the light of these considerations, the aims of this research was to investigate the biosynthesis of galactooligosaccharides (GOS) derived from porungo cheese whey, using immobilized $\beta$-galactosidase. This substrate has not been explored before in bioprocess. Different supports of immobilization were tested, and the reaction was optimized concerning the substrate concentration and temperature.

\section{Materials and methods}

\section{$2.1 \beta$-galactosidase immobilization}

The Kluyveromyces lactis $\beta$-galactosidase enzyme, Maxilact LGi 5000 (DSM of Brazil), was donated by Global Food Company (São Paulo, SP) in liquid formulation, with a declared activity of $\geq 5000$ Natural Lactase Unit (NLU) per gram of comercial enzyme. The immobilization of $\beta$-galactosidase was carried out in two different ways: 1) using calcium alginate (Ca-alginate) as innert support; and 2) calcium alginate treated with Concanavalina-A (Ca-ConA), following the methodology described by Mörschbächer et al. (2016). The diluted enzyme was added to $5 \%$ sodium alginate solution to a final enzyme activity of $250 \mathrm{U}$ per $\mathrm{mL}$ of alginate. This mixture was dripped in to a $0.05 \mathrm{M}$ calcium chloride solution $\left(\mathrm{CaCl}_{2}\right)$ using a needlecoupled syringe $(6 \times 0.25 \mathrm{~mm})$. Afterward, the formed beads $(2.49 \mathrm{~mm})$ were gently agitated for $30 \mathrm{~min}$ and kept in contact with this solution for $1 \mathrm{~h}$, at $4{ }^{\circ} \mathrm{C}$ to stabilize the system. The beads were then rinsed with a $0.1 \mathrm{M}$ potassium phosphate buffer solution ( $\mathrm{pH}$ 7.0) to be used in subsequent experiments. The Ca-ConA was prepared through the addition of $4 \mathrm{mg}$ of ConA for each $\mathrm{mL}$ of diluted enzyme. Then, this complex was added in to a $5 \%$ sodium alginate solution to a final enzyme activity of $250 \mathrm{U}$ per $\mathrm{mL}$ of alginate and this mixture was dripped in $0.05 \mathrm{M}$ calcium chloride solution $\left(\mathrm{CaCl}_{2}\right)$ through a needle-coupled syringe $(6 \times 0.25 \mathrm{~mm})$. The beads were agitated for $30 \mathrm{~min}$ and kept in contact with this solution as described above.

\subsection{Activity of free and immobilized $\beta$-galactosidase}

The determination of free $\beta$-galactosidase activity was carried out using ONPG (o-nitrophenyl- $\beta$-D-galactopyranoside) as substrate, according to the methodology described by Klein et al. (2013). The reaction occurred from $50 \mu \mathrm{L}$ of the diluted enzyme and $0.5 \mathrm{~mL}$ of activity buffer composed of $0.1 \mathrm{M}$ potassium phosphate buffer and $1.5 \mathrm{mM}$ magnesium chloride solution $\left(\mathrm{MgCl}_{2}\right)$ containing $10 \mathrm{mM}$ ONPG for $2 \mathrm{~min}$. The activity for $\beta$-galactosidase immobilized was determined from a volume of spheres equal to $50 \mu \mathrm{L}$ (total of 7 beads). The reactions were stopped by the addition of $0.1 \mathrm{M}$ of sodium carbonate-bicarbonate buffer $(\mathrm{pH} 10)$. The o-nitrophenol (ONP) released was determined using spectrophotometer at $415 \mathrm{~nm}$. One unit of enzymatic activity (U) was defined as the amount of enzyme required to release $1 \mu \mathrm{mol}$ of o-nitrophenol per minute, under analysis conditions.

\subsection{Optima $p H$ and temperature for free and immobilized $\beta$-galactosidase}

The optimum $\mathrm{pH}$ for free and immobilized $\beta$-galactosidase was evaluated from $0.1 \mathrm{M}$ potassium phosphate buffer solution containing $1.5 \mathrm{mM}$ magnesium chloride solution $\left(\mathrm{MgCl}_{2}\right)$ at $37^{\circ} \mathrm{C}$, varying the $\mathrm{pH}$ from 5.5 to 8.0. Likewise, the temperature for free and immobilized $\beta$-galactosidase was evaluated ranging from $10^{\circ} \mathrm{C}$ to $70^{\circ} \mathrm{C}$, at $\mathrm{pH} 7.0$. The reaction occurred using $50 \mu \mathrm{L}$ (free $\beta$-galactosidase) or 7 beads (immobilized $\beta$-galactosidase) and $0.5 \mathrm{~mL}$ of activity buffer containing 10 $\mathrm{mM}$ ONPG for $2 \mathrm{~min}$.

\subsection{Galactooligosaccharides (GOS) production}

The synthesis of GOS was carried out in two steps. Firstly, different substrates were tested, and subsequently, different concentrations of porungo cheese whey and temperatures were evaluated, both using the Ca-alginate support. The first step was performed using two different substrates: 1) lactose $50 \mathrm{~g} \mathrm{~L}^{-1}$ diluted in $0.1 \mathrm{M}$ phosphate buffer ( $\mathrm{pH} 7.0$ ), or 2) porungo cheese whey ( $\mathrm{pH}$ 7.0). Whey proteins were hydrolyzed with commercial protease (Alcalase 2.4 L, $2.4 \mathrm{UA}-\mathrm{A} \mathrm{g}^{-1}$, Tovani Benzaquen Ingredients, São Paulo, Brazil), at $\mathrm{pH} 8.5,55^{\circ} \mathrm{C}$ for $3 \mathrm{~h}$. This procedure was carried out to avoid protein precipitation during the GOS production process. The GOS production was conducted in conical flasks of $125 \mathrm{~mL}$ containing $8 \mathrm{~mL}$ of immobilized $\beta$-galactosidase and $20 \mathrm{~mL}$ of substrate. The temperature and the agitation were controlled in an orbital shaker at $50 \mathrm{rpm}$ and $37^{\circ} \mathrm{C}$, in a time reaction of $180 \mathrm{~min}$. Duplicate samples were collected periodically and immediately placed in ice bath to stop the reaction. The second experimental step was conducted using porungo cheese whey containing different lactose concentrations $\left(200 \mathrm{~g} \mathrm{~L}^{-1}\right.$ and $\left.400 \mathrm{~g} \mathrm{~L}^{-1}\right)$ and under different temperatures $\left(37^{\circ} \mathrm{C}, 46^{\circ} \mathrm{C}\right.$ and $55^{\circ} \mathrm{C}$ ). The tests were conducted in conical flasks of $125 \mathrm{~mL}$ containing $8 \mathrm{~mL}$ beads with immobilized $\beta$-galactosidase in $20 \mathrm{~mL}$ in an orbital shaker at $50 \mathrm{rpm}$, during $180 \mathrm{~min}$. Duplicate 
samples were collected periodically and subjected to ice bath to stop the enzymatic reaction.

\subsection{Analytical methods}

Analysis of galactooligosaccharides (GOS) and monosaccharides was performed by High Performance Liquid Chromatography (HPLC), (Shimadzu, Aminex HPX-87C column (300 x 7.8 mm)), according to the methodology described by Klein et al. (2013). The samples were centrifuged $(3000 \times \mathrm{g}$ for $15 \mathrm{~min})$ and the supernatant was filtered on cellulose-acetate membrane $(0.22 \mu \mathrm{m})$. Ultrapure water was used as eluent at a flow rate of $0.6 \mathrm{~mL} \mathrm{~min}{ }^{-1}$ at $85^{\circ} \mathrm{C}$. Standards for lactose, glucose and galactose were used. GOS concentrations were calculated as raffinose equivalents from an external raffinose standard. The GOS yield (\%) was defined as the percentage of GOS produced compared with the weight of initial lactose in the reaction medium; lactose conversion (\%) was defined as a relation of lactose consumption in the reaction with its initial concentration.

\section{Results and discussion}

\subsection{Optima $\mathrm{pH}$ and temperature for enzyme activity}

The effect of $\mathrm{pH}$ and temperature on the relative activity of the free and immobilized $\beta$-galactosidases are represented in Figure 1.

Immobilization in Ca-alginate extended the optimum $\mathrm{pH}$ range of the enzyme to a broader range of 6.5 to 7.5 when compared with optimum $\mathrm{pH}$ of the free enzyme (Figure 1a). Using this immobilization support, the enzyme activity was increased to a more acidic $\mathrm{pH}$ ( 5.5 and 6.0 ), with more than $45 \%$ of the activity remaining at $\mathrm{pH} 6$, compared to $36 \%$ for to free enzyme. This might be due to the protection effect provided by the immobilization support, allowing operational stability (Grosová et al., 2008). In Ca-ConA support, a higher enzymatic activity was observed in lower $\mathrm{pH}$ (6.0). The optimal $\mathrm{pH}$ range shift to an acidic value agrees with reports by Huang et al. (1996), who studied the enzyme $\beta$-galactosidase immobilized on silanized glass beads. In their research, the enzymatic activity was determined in the $\mathrm{pH}$ range of 4.0 to 9.0 and temperature from $20^{\circ} \mathrm{C}$ to $60^{\circ} \mathrm{C}$, presenting a similar behavior found in our work, when compared to free enzyme ( $\mathrm{pH}$ 7.0). The authors observed the same behavior in relation to the optimum temperature, in which the higher activity was found at lower temperature $\left(40^{\circ} \mathrm{C}\right)$ for immobilized enzyme compared to the free form $\left(45^{\circ} \mathrm{C}\right)$. However, the support Ca-ConA did not perform satisfactorily for the enzymatic activity when compared to Ca-alginate support, as it led to lower enzymatic activity values (less than 54\%), being even lower than those observed for free enzyme. This effect was observed at $\mathrm{pH} 7.0$, under which the relative enzymatic activity was $79 \%$ for free enzyme, compared to $32 \%$ in Ca-ConA. In Ca-alginate support, maximum enzymatic activity was observed for $\mathrm{pH}$ ranging from 7.0 to 7.5 , corresponding to $100 \%$ of relative enzymatic activity.

The effect of temperature on enzymatic activity is shown in Figure $1 \mathrm{~b}$. The maximum activity for the immobilized $\beta$-galactosidase is obtained at about $37^{\circ} \mathrm{C}$ and $35^{\circ} \mathrm{C}$ in Ca-alginate and $\mathrm{Ca}-\mathrm{ConA}$,
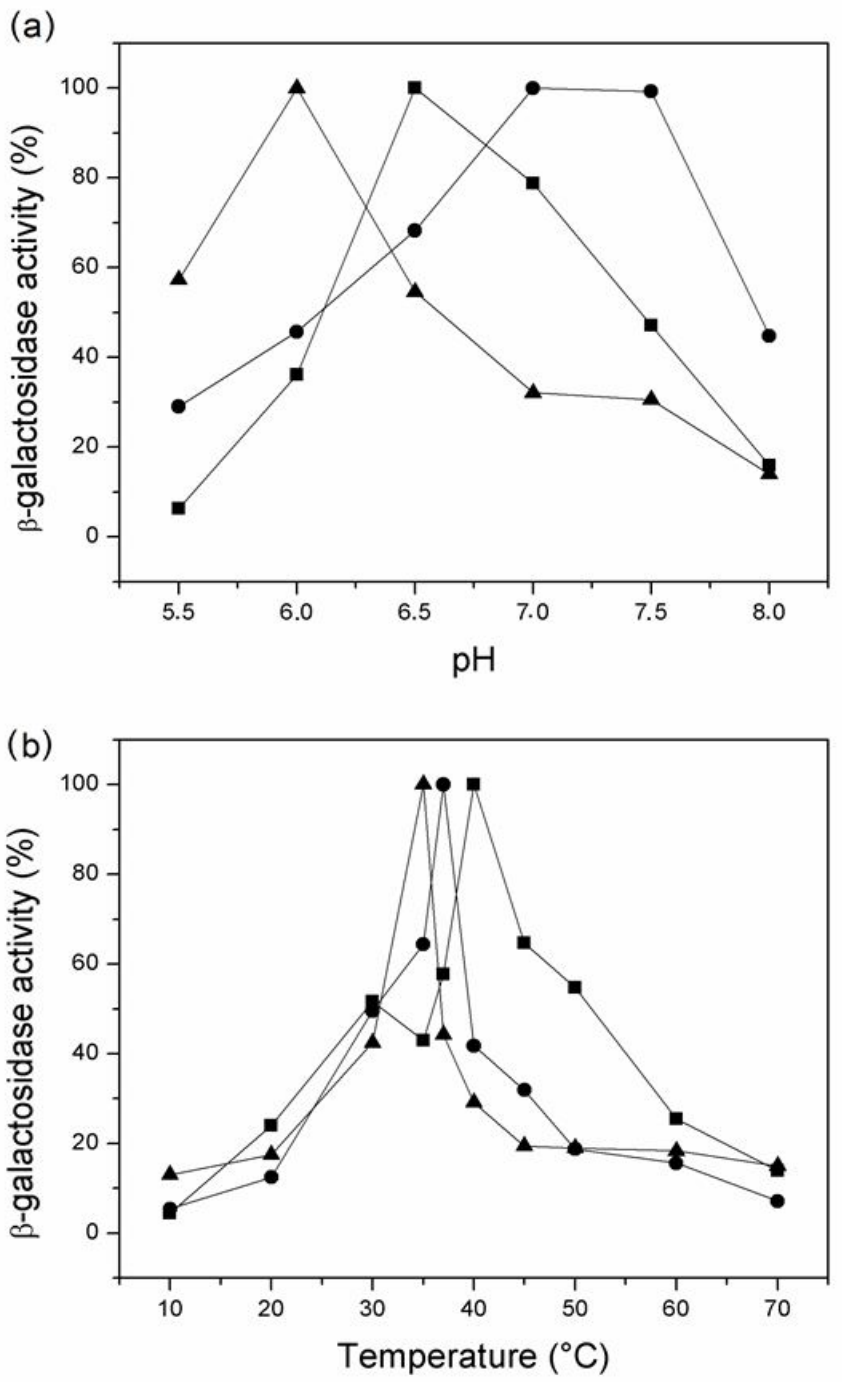

Figure 1. Effect of $\mathrm{pH}(\mathrm{a})$ and temperature (b) on free $\beta$-galactosidase activity ( $\bullet$ ), immobilized on Ca-alginate ( $)$ and immobilized on Ca-ConA $\beta$-galactosidase complex $(\boldsymbol{\Lambda})$.

respectively, compared to $40^{\circ} \mathrm{C}$ for the free enzyme. Surprisingly, the temperature range for the immobilized enzyme on the two immobilization supports tested was narrower than the free enzyme range, a somewhat not expected behavior because the intent of the immobilization is to give greater protection to the enzyme, and consequently, to provide increased enzymatic activity under more extreme conditions. Escobar et al. (2014), also verified a higher enzymatic activity of free $\beta$-galactosidase compared to the Ca-alginate immobilized enzyme when investigating the lactose hydrolysis in whey permeate. An explanation for this can be explained based on diffusional effects, which produces resistances to mass transfer in the matrix of immobilization. Enzyme immobilization in alginate systems enables several interesting features, such as high biocatalytic density. However, the main limitation of this technique is the diffusional barrier of substrates and products through the gel matrix. High enzyme density can also difficult the contact of enzyme and substrate in the inner environment of the beads, again causing limitations of 
mass transfer (Gabardo et al., 2011; Pilkington et al., 1998). In this context, Ca-alginate support was the most promising support observed in this research, since it provided an increase of the range of the relative enzymatic activity. In this sense, Ca-alginate was the support used to conduce the testes of GOS production.

\subsection{Galactooligosaccharides (GOS) production}

The study of galactooligosaccharides (GOS) production was carried out in two steps. In the first, different lactose sources (substrates) were evaluated. Subsequently, different concentrations and temperatures were evaluated. Galactooligosaccharides are non-digestible oligosaccharides, used as prebiotics in food ingredients, and its regular consumption can promote the growth of beneficial intestinal microbiota (Lactobacilos sp and Bifidobacterium sp), which are associated with positive health effects when applied in human diets (Grosová et al., 2008). The kinetics of galactooligosaccharides synthesis from porungo cheese whey and lactose solution $50 \mathrm{~g} \mathrm{~L}^{-1}$ is shown in Figure 2. Porungo cheese is an artisanal cheese manufactured using raw milk and contain $4.3 \%$ of lactose concentration according previous studies carried out by our group (Coelho et al., 2020), being able as a potential and alternative source of carbon to GOS production. The galactooligosaccharides synthesis from porungo cheese whey was higher than that observed for lactose solution, reaching yields of $63.1 \%$ compared to $41.1 \%$, respectively. Moreover, the kinetics of GOS production from lactose solution was slower,

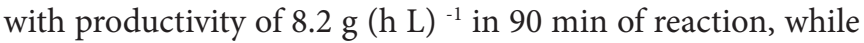
the productivity from porungo cheese whey was $13.6 \mathrm{~g}(\mathrm{~h} \mathrm{~L})$ ${ }^{-1}$, which demonstrates the potential biotechnological use of porungo cheese whey to synthesize GOS.

In the second step of experiments, the highest GOS synthesis was observed from porungo cheese whey with lactose concentration of $400 \mathrm{~g} \mathrm{~L}^{-1}$ and temperature of $46^{\circ} \mathrm{C}$ (Figure 3).

This behavior was similar to those found by Santos et al. (2009), who studied the production of galactooligosaccharides from Scopulariopis sp. at temperatures of $35^{\circ} \mathrm{C}, 45^{\circ} \mathrm{C}$ and $60^{\circ} \mathrm{C}$, using $40 \%$ of lactose concentration and free enzyme $\left(10 \mathrm{U} \mathrm{mL}^{-1}\right)$, obtaining a better performance at $45^{\circ} \mathrm{C}$, reaching a GOS yield of $20 \%$. However, according to Urrutia et al. (2013), higher GOS values were found using $\beta$-galactosidase of $K$. lactis, reaching a maximum yield of $42 \%$ from $400 \mathrm{~g} \mathrm{~L}^{-1}$ of lactose and the free enzyme concentration of $15 \mathrm{U} \mathrm{mL}^{-1}$. The maximum GOS yield was $17.6 \%$ in whey concentration of $200 \mathrm{~g} \mathrm{~L}^{-1}$ (Figure $4 \mathrm{a}$ ) and $17.7 \%$ in whey concentration of $400 \mathrm{~g} \mathrm{~L}^{-1}$ (Figure $4 \mathrm{~b}$ ), at temperature of $46^{\circ} \mathrm{C}$. It is observed an increase in GOS production from $120 \mathrm{~min}$ of reaction under the condition of $400 \mathrm{~g} \mathrm{~L}^{-1}$ and $46^{\circ} \mathrm{C}$ (Figure $4 \mathrm{~b}$ ), indicating longer required reaction time to reach highest values of bioconversion, a fact represented by Figure 5, which shows $100 \mathrm{~g} \mathrm{~L}^{-1}$ residual lactose, indicating that it was not fully consumed in the reaction. Moreover, in Figure 5, it can be observed that the lactose was converted not only into GOS but also in its monosaccharides, confirming the potential of the enzyme for reactions of hydrolysis and in the transgalactosylation (Fai \& Pastore 2015).

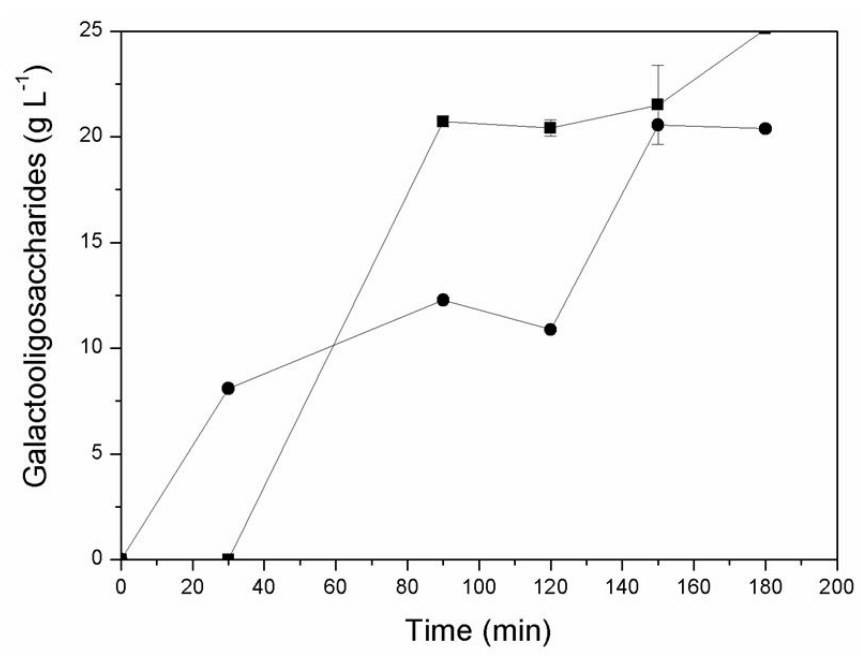

Figure 2. Kinetics of galactooligosaccharides (GOS) production from porungo cheese whey $(\bullet)$ and in lactose solution $(\bullet)$ in rotatory shaker at $50 \mathrm{rpm}$ and $37^{\circ} \mathrm{C}$.

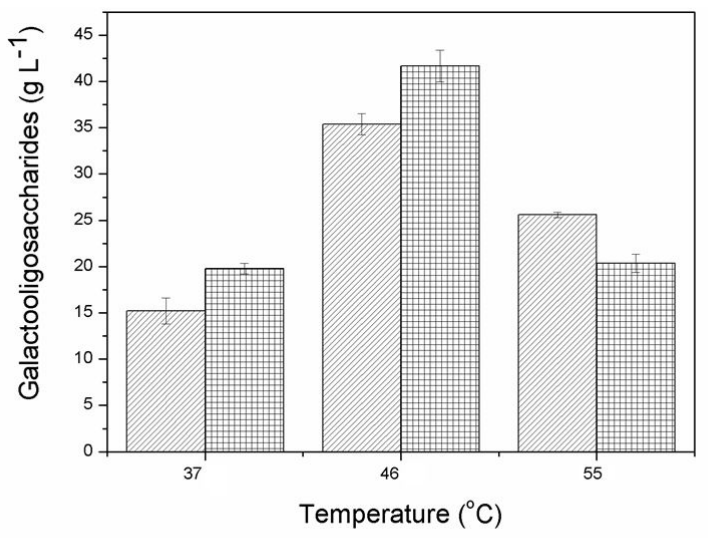

Porungo cheese whey concentration of $200 \mathrm{~g} \mathrm{~L}^{-1}$ (गया) and $400 \mathrm{~g} \mathrm{~L}^{-1}$ (曲冊).

Figure 3. Influence of temperature and porungo cheese whey concentration on galactooligosaccharides (GOS) production in rotatory shaker at $50 \mathrm{rpm}$.

The GOS produced in this work was a trisaccharide. The yield of GOS obtained in this work is similar to what was reported by Martínez-Villaluenga et al. (2008), who found yields of $20 \%$ of GOS 3 (trisaccharide) under reaction conditions between $40^{\circ} \mathrm{C}$ and $50^{\circ} \mathrm{C}$ using $\beta$-galactosidase obtained from $K$. lactis. In general, reaction products (GOS) have the structure $\mathrm{Gal}_{\mathrm{n}}-\mathrm{Glc}$, where $\mathrm{n}$ indicates the degree of polymerization, typically between 1 to 5 , and may have different types of bonds, such as Gal $(\beta 1 \rightarrow 3)$, Gal $(\beta 1 \rightarrow 4)$, and Gal $(\beta 1 \rightarrow 6)$ (Gosling et al., 2011; Nath et al., 2013). Moreover, besides the possibility of different types of GOS formed for the same enzyme, when they are obtained by different microorganisms, they can also influence the type of bonding and degree of polymerization obtained. $K$. lactis $\beta$-galactosidase is characterized by producing GOS ranging from disaccharides to tetrasaccharides; Aspergillus oryzae $\beta$-galactosidase produces GOS ranging from disaccharides to hexasaccharides; and Bacillus circulans $\beta$-galactosidase have produced GOS ranging 

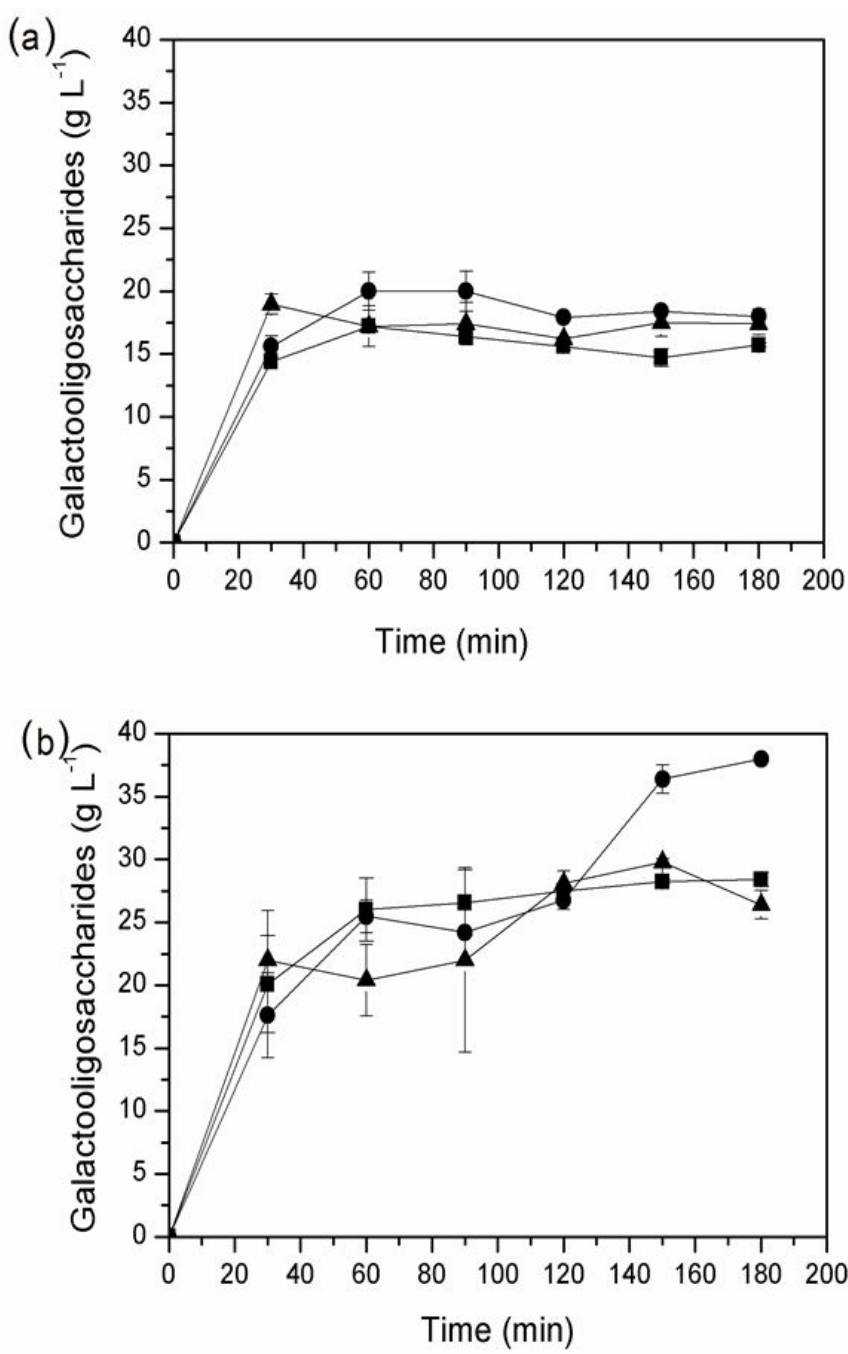

Figure 4. Kinetics of galactooligosaccharides (GOS) production in adjusted cheese whey for lactose concentration $200 \mathrm{~g} \mathrm{~L}^{-1}$ (a) and lactose concentration adjusted to $400 \mathrm{~g} \mathrm{~L}^{-1}(\mathrm{~b})$ at temperatures of $37^{\circ} \mathrm{C} \mathrm{(-)}$; $46^{\circ} \mathrm{C}(\bullet)$; and $55^{\circ} \mathrm{C}(\boldsymbol{\Delta})$.

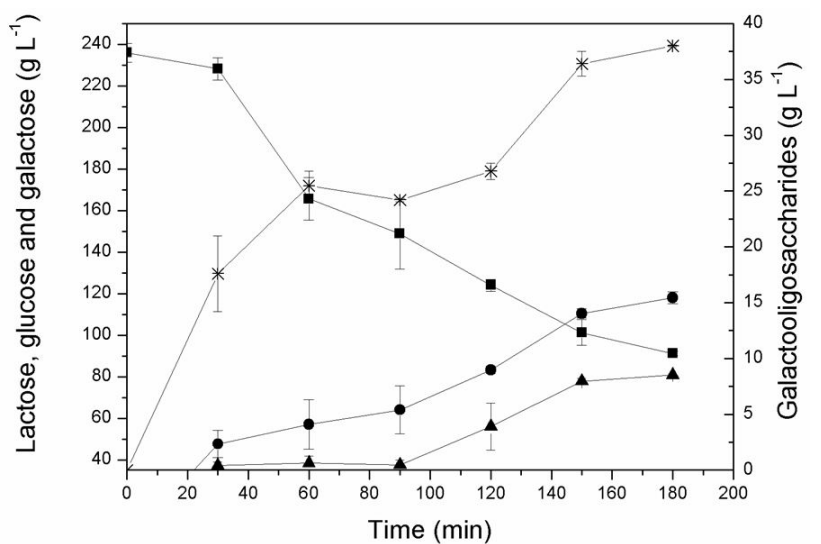

Figure 5. kinetics of porungo cheese whey conversion in concentration of $400 \mathrm{~g} \mathrm{~L}^{-1}$ at $46^{\circ} \mathrm{C}$ for $\beta$-galactosidase reaction products. Lactose (-); glucose $(\bullet)$; galactose $(\boldsymbol{\Delta})$; GOS $\left(^{\star}\right)$.

from disaccharides to pentasaccharides (Gosling et al., 2011; Frenzel et al., 2015).

\section{Conclusion}

The Ca-alginate immobilization technique increased the optimal $\mathrm{pH}$ range of $\beta$-galactosidase and the thermal stability of immobilized $\beta$-galactosidase positively influences the operating conditions in the present work, since the transgalactosylation reaction is favored at high temperatures. The yields obtained for GOS demonstrated the ability to use porungo cheese whey in this bioprocess, being a maximum yield at $46^{\circ} \mathrm{C}$ and porungo cheese whey concentration of $400 \mathrm{~g} \mathrm{~L}^{-1}$. In this context, it is evidenced the biotechnological potential of porungo cheese whey in the synthesis of GOS, which is a promising alternative carbon source, allowing the use of agro-industrial by-product from the dairy industry to obtain added-value biomolecules to be used in the food industry.

\section{Acknowledgements}

The authors wish to thank CNPq and UFSCar (Brazil) for the financial support of this research and scholarships for the first author.

\section{References}

Christensen, A. D., Kádár, Z., Oleskowicz-Popiel, P., \& Thomsen, M. H. (2011). Production of bioethanol from organic whey using Kluyveromyces marxianus. Journal of Industrial Microbiology \& Biotechnology, 38(2), 283-289. http://dx.doi.org/10.1007/s10295010-0771-0. PMid:20632200.

Coelho, R. J. S., Gabardo, S., Marim, A. V. C., Bolognesi, L. S., Pimentel, N. J. Fo., \& Ayub, M. A. Z. (2020). Porungo cheese whey: a new substrate to produce $\beta$-galactosidase. Annals of the Brazilian Academy of Sciences. In press.

Das, M., Raychaudhuri, A., \& Ghosh, S. K. (2016). Supply chain of bioethanol production from whey: a review. Procedia Environmental Sciences, 35, 833-846. http://dx.doi.org/10.1016/j.proenv.2016.07.100.

Davani-Davari, D., Negahdaripour, M., Karimzadeh, I., Seifan, M., Mohkam, M., Masoumi, S. J., Berenjian, A., \& Ghasemi, Y. (2019). Prebiotics: definition, types, sources, mechanisms, and clinical applications. Foods, 8(3), 92. http://dx.doi.org/10.3390/foods8030092. PMid:30857316.

Escobar, G. P., Souza, C. F. V., \& Lehn, D. N. (2014). Avaliação de $\beta$-galactosidase livre e imobilizada na hidrólise da lactose do permeado de soro de queijo. Revista Caderno Pedagógico, 11(1), 117-129. Retrieved from http://www.univates.br/revistas/index. $\mathrm{php} / \mathrm{cadped} /$ article/view/903/892

Fai, A. E. C., \& Pastore, G. M. (2015). Galactooligosaccharides: production, health benefits, application to foods and perspectives. Scientia Agropecuaria, 6(1), 69-81. http://dx.doi.org/10.17268/sci. agropecu.2015.01.07.

Fangmeier, M., Kemerich, G. T., Machado, B. L., Maciel, M. J., \& Souza, C. F. V. D. (2019). Effects of cow, goat, and buffalo milk on the characteristics of cream cheese with whey retention. Food Science and Technology, 39(Suppl. 1), 122-128. http://dx.doi.org/10.1590/fst.39317.

Freitas, F. F., Marquez, L. D., Ribeiro, G. P., Brandão, G. C., Cardoso, V. L., \& Ribeiro, E. J. (2011). A comparison of the kinetic properties of free and immobilized Aspergillus oryzae $\beta$-galactosidase. Biochemical Engineering Journal, 58-59, 33-38. http://dx.doi.org/10.1016/j. bej.2011.08.011.

Frenzel, M., Zerge, K., Clawin-Rädecker, I., \& Lorenzen, P. C. (2015). Comparison of the galacto-oligosaccharide forming activity of 
different $\beta$-galactosidases. Lebensmittel-Wissenschaft + Technologie, 60(2), 1068-1071. http://dx.doi.org/10.1016/j.lwt.2014.10.064.

Gabardo, S., Rech, R., \& Ayub, M. A. Z. (2011). Determination of lactose and ethanol diffusion coefficients in calcium alginate gel spheres: predicting values to be used in immobilized bioreactors. Journal of Chemical \& Engineering Data, 56(5), 2305-2309. http:// dx.doi.org/10.1021/je101288g.

Gabardo, S., Rech, R., Rosa, C. A., \& Ayub, M. A. Z. (2014). Dynamics of ethanol production from whey and whey permeate by immobilized strains of Kluyveromyces marxianus in batch and continuous bioreactors. Renewable Energy, 69, 89-96. http://dx.doi.org/10.1016/j.renene.2014.03.023.

Gibson, G. R., \& Roberfroid, M. B. (1995). Dietary modulation of the human colonic microbiota: introducing the concept of prebiotics. The Journal of Nutrition, 125(6), 1401-1412. http://dx.doi.org/10.1093/ jn/125.6.1401. PMid:7782892.

Gibson, G. R., Scott, K. P., Rastall, R. A., Tuohy, K. M., Hotchkiss, A., Dubert-Ferrandon, A., Gareau, M., Murphy, E. F., Saulnier, D., Loh, G., Macfarlane, S., Delzenne, N., Ringel, Y., Kozianowski, G., Dickmann, R., Lenoir-Wijnkoop, I., Walker, C., \& Buddington, R. (2010). Dietary prebiotics: current status and new definition. Food Science and Technology Bulletin: Functional Foods, 7(1), 1-19. http:// dx.doi.org/10.1616/1476-2137.15880.

Gosling, A., Stevens, G. W., Barber, A. R., Kentish, S. E., \& Gras, S. L. (2011). Effect of the substrate concentration and water activity on the yield and rate of the transfer reaction of $\beta$-galactosidase from Bacillus circulans. Journal of Agricultural and Food Chemistry, 59(7), 3366-3372. http://dx.doi.org/10.1021/jf104397w. PMid:21375323.

Grosová, Z., Rosenberg, M., \& Rebroš, M. (2008). Perspectives and applications of immobilised $\beta$-galactosidase in food industry: a review. Czech Journal of Food Sciences, 26(1), 1-14. http://dx.doi. org/10.17221/1134-CJFS.

Guimarães, P. M., Teixeira, J. A., \& Domingues, L. (2010). Fermentation of lactose to bio-ethanol by yeasts as part of integrated solutions for the valorisation of cheese whey. Biotechnology Advances, 28(3), 375-384. http://dx.doi.org/10.1016/j.biotechadv.2010.02.002. PMid:20153415.

Haider, T., \& Husain, Q. (2007). Calcium alginate entrapped preparations of Aspergillus oryzae $\beta$ galactosidase: its stability and applications in the hydrolysis of lactose. International Journal of Biological Macromolecules, 41(1), 72-80. http://dx.doi.org/10.1016/j. ijbiomac.2007.01.001. PMid:17298841.

Huang, X. L., Walsh, M. K., \& Swaisgood, H. E. (1996). Simultaneous isolation and immobilization of streptavidin- $\beta$-galactosidase: Some kinetic characteristics of the immobilized enzyme and regeneration of bioreactors. Enzyme and Microbial Technology, 19(5), 378-383. http://dx.doi.org/10.1016/S0141-0229(96)00015-4.

Kelleher, C. M., Aydogdu, T., Murphy, K. M., O’Mahony, J. A., Kelly, A. L., O'Callaghan, D. J., \& McCarthy, N. A. (2020). The effect of protein profile and preheating on denaturation of whey proteins and development of viscosity in milk protein beverages during heat treatment. International Journal of Dairy Technology, 73(3), 494-501. http://dx.doi.org/10.1111/1471-0307.12679.

Klein, M. P., Fallavena, L. P., Schöffer, J. D. N., Ayub, M. A., Rodrigues, R. C., Ninow, J. L., \& Hertz, P. F. (2013). High stability of immobilized $\beta$-D-galactosidase for lactose hydrolysis and galactooligosaccharides synthesis. Carbohydrate Polymers, 95(1), 465-470. http://dx.doi. org/10.1016/j.carbpol.2013.02.044. PMid:23618294.
Laufenberg, G., Kunz, B., \& Nystroem, M. (2003). Transformation of vegetable waste into value added products:: (A) the upgrading concept; (B) practical implementations. Bioresource Technology, 87(2), 167-198. http://dx.doi.org/10.1016/S0960-8524(02)00167-0. PMid:12765356.

Martínez-Villaluenga, C., Cardelle-Cobas, A., Corzo, N., Olano, A., \& Villamiel, M. (2008). Optimization of conditions for galactooligosaccharide synthesis during lactose hydrolysis by $\beta$-galactosidase from Kluyveromyces lactis (Lactozym $3000 \mathrm{~L} \mathrm{HP}$ G). Food Chemistry, 107(1), 258-264. http://dx.doi.org/10.1016/j. foodchem.2007.08.011.

Mörschbächer, A. P., Volpato, G., \& Souza, C. F. V. D. (2016). Kluyveromyces lactis $\beta$-galactosidase immobilization in calcium alginate spheres and gelatin for hydrolysis of cheese whey lactose. Ciência Rural, 46(5), 921-926. http://dx.doi.org/10.1590/0103-8478cr20150833.

Nath, A., Bhattacharjee, C., \& Chowdhury, R. (2013). Synthesis and separation of galacto-oligosaccharides using membrane bioreactor. Desalination, 316(1), 31-41. http://dx.doi.org/10.1016/j.desal.2013.01.024.

Pezzo, M. (2017). Porungo: queijo tradicional da Região do Campus Lagoa do Sino está no centro de parceria entre pesquisadores e produtores locais. Revista UFSCar, 2, 36-42. Retrieved from http:// revista.ufscar.br/edicoes-online/02/files/basic-html/page36.html

Pilkington, P. H., Margaritis, A., \& Mensour, N. A. (1998). Mass transfer characteristics of immobilized cells used in fermentation processes. Critical Reviews in Biotechnology, 18(2-3), 237-255. http://dx.doi. org/10.1080/0738-859891224239.

Prazeres, A. R., Carvalho, F., \& Rivas, J. (2012). Cheese whey management: a review. Journal of Environmental Management, 110, 48-68. http:// dx.doi.org/10.1016/j.jenvman.2012.05.018. PMid:22721610.

Rasouli, M., Abbasi, S., Azarikia, F., \& Ettelaie, R. (2020). On the heat stability of whey protein: Effect of sodium hexametaphosphate. International Journal of Dairy Technology, 73(1), 46-56. http://dx.doi. org/10.1111/1471-0307.12626.

Roberfroid, M. B. (2008). Prebiotics: concept, definition, criteria, methodologies, and products. In G. R. Gibson \& M. B. Roberfroid (Eds.), Handbook of prebiotics (Chap. 3, pp. 49-78). Boca Raton: CRC Press. http://dx.doi.org/10.1201/9780849381829.ch3.

Santos, R. D., Simiqueli, A. P. R., \& Pastore, G. M. (2009). Produção de galactooligossacarídeo por Scopulariopis sp. Food Science and Technology, 29(3), 682-689. http://dx.doi.org/10.1590/S010120612009000300035.

Siso, M. G. (1996). The biotechnological utilization of cheese whey: a review. Bioresource Technology, 57(1), 1-11. http://dx.doi. org/10.1016/0960-8524(96)00036-3.

Trindade, M. B., Soares, B. C. V., Scudino, H., Guimarães, J. T., Esmerino, E. A., Freitas, M. Q., Pimentel, T. C., Silva, M. C., Souza, S. L. Q., Almada, R. B., \& Cruz, A. G. (2019). Cheese whey exploitation in Brazil: a questionnaire survey. Food Science and Technology, 39(3), 788-791. http://dx.doi.org/10.1590/fst.07419.

Urrutia, P., Rodriguez-Colinas, B., Fernandez-Arrojo, L., Ballesteros, A. O., Wilson, L., Illanes, A., \& Plou, F. J. (2013). Detailed analysis of galactooligosaccharides synthesis with $\beta$-galactosidase from Aspergillus oryzae. Journal of Agricultural and Food Chemistry, 61(5), 1081-1087. http://dx.doi.org/10.1021/jf304354u. PMid:23330921. 